\title{
Studies on the Decline of Bovine Virus Diarrhoea Virus (BVDV) Maternal Antibodies and Detectability of BVDV in Persistently Infected Calves
}

Persistently infected (PI) animals play a significant role in spread and transmission of bovine virus diarrhoea virus (BVDV) (Duffell \& Harkness 1985). The identification and removal of PI cattle from the herd is of great importance in the control of BVDV. Although PI animals often show various degrees of growth retardation and unthrifty appearance, a significant proportion is clinically normal. PI animals are often seronegative (Duffell \& Harkness 1985), but calves may be tested seropositive because of the presence of maternal immunity (Meyling \& Jensen 1988). The passively derived BVDV antibodies may interfere with the ability to detect virus. Considering the importance of early recognition of PI calves, it is essential to determine the earliest time when PI animals can safely be diagnosed in the herd.

The goal of this investigation was to get information in this field, since published data are scarce. Detailed data are only published by Meyling \& Jensen (1988), who tested 1 PI calf after colostrum intake and subsequently failed to isolate virus until 5 weeks later, when the passively acquired antibodies had disappeared.

In the present study, the connection between BVDV maternal antibody and virus detection was investigated in PI animals. In 1 farm, 12 calves born in the course of 4 weeks suspected to be PI with BVDV were selected. The ani- mals were fed and kept as any other calf on the farm. Blood samples were taken 5 times at a 4 week interval and tested for BVDV and BVDV antibody. The age of the calves at first sampling varied between 0-4 weeks (Table 1). As a first screening, an indirect ELISA was applied using the NADL strain (Qvist submitted).

Neutralizing antibody titers of samples positive in ELISA were determined with the DK133 strain in the virus neutralization test according to Meyling \& Jensen (1988). Examination for BVDV was performed by the use of an immunoperoxidase technique (Meyling 1984).

The results of BVDV antibody and BVDV detection indicated that 11 (Nos. 1-11) calves were PI, while calf No. 12 was immunocompetent (Table 1). Seven out of the 11 PI calves proved to be seropositive in the first sampling. In calf No.11 after colostrum ingestion, a BVDV antibody titer as high as 2048 was found. Four weeks later it was 384 , and at 8 weeks of age no antibodies could be demonstrated. On the other hand, in calf 10 the initial antibody titer of 192 decreased to undetectable level in 4 weeks. In calf No. 5 a titer of 24 was found at 6 weeks of age, which decreased to undetectable level by the subsequent sampling 4 weeks later. This was the latest time when BVDV antibody could be detected. Taking into consideration data ob- 
Table 1. BVDV antibody and BVDV detection in 11 persistently infected (PI) animals (Nos. 1-11) and in 1 immunocompetent calf (No. 12) during the first 20 weeks after birth.

\begin{tabular}{|c|c|c|c|c|c|c|c|c|c|c|c|}
\hline \multirow[b]{2}{*}{$\begin{array}{l}\text { Calf } \\
\text { No }\end{array}$} & \multicolumn{11}{|c|}{ Week number } \\
\hline & $\begin{array}{c}0 \\
\mathrm{Ab} \mathrm{Ag}\end{array}$ & $\stackrel{2}{\mathrm{Ab} \mathrm{Ag}}$ & $\begin{array}{c}4 \\
\mathrm{Ab} \mathrm{Ag}\end{array}$ & $\begin{array}{c}6 \\
\mathrm{Ab} \mathrm{Ag}\end{array}$ & $\begin{array}{c}8 \\
\mathrm{Ab} \mathrm{Ag}\end{array}$ & $\begin{array}{c}10 \\
\mathrm{Ab} \mathrm{Ag}\end{array}$ & $\begin{array}{c}12 \\
\mathrm{Ab} \mathrm{Ag}\end{array}$ & $\begin{array}{c}14 \\
\mathrm{Ab} \mathrm{Ag}\end{array}$ & $\begin{array}{c}16 \\
\mathrm{Ab} \mathrm{Ag}\end{array}$ & $\begin{array}{c}18 \\
\mathrm{Ab} \mathrm{Ag}\end{array}$ & $\begin{array}{c}20 \\
\mathrm{Ab} \mathrm{Ag}\end{array}$ \\
\hline 1 & & & 640 & & $0+$ & & $0+$ & & $0+$ & & $0+$ \\
\hline 2 & & & 480 & & $0+$ & & $0+$ & & $0+$ & & $0+$ \\
\hline 3 & & & $0+$ & & $0+$ & & $0+$ & & $0+$ & & $0+$ \\
\hline 4 & & & $0+$ & & $0+$ & & $0+$ & & $0+$ & & $0+$ \\
\hline 5 & & 5120 & 240 & & $0+$ & & $0+$ & & $0+$ & & \\
\hline 6 & & 160 & $0+$ & & $0+$ & & $0+$ & & $0+$ & & \\
\hline 7 & & $0+$ & & $0+$ & & $0+$ & & $0+$ & & $0+$ & \\
\hline 8 & & $0+$ & & $0+$ & & $0+$ & & $0+$ & & $0+$ & \\
\hline 9 & & 1920 & $0+$ & & $0+$ & & $0+$ & & $0+$ & & \\
\hline 10 & 1920 & & $0+$ & & $0+$ & & $0+$ & & $0+$ & & \\
\hline 11 & 20480 & & 3840 & & $0+$ & & $0+$ & & $0+$ & & \\
\hline 12 & & 10240 & 5120 & & 960 & & 480 & & 320 & & \\
\hline
\end{tabular}

Ab: Antibody titer

Ag: Detection of virus: $+=$ yes, $0=$ no.

tained in calves Nos. 1, 2, 6, 10 and 11, this low antibody titer had to disappear in a short time. In the presence of BVDV antibodies, no virus could be detected, whereas BVDV could be demonstrated repeatedly in all the 11 PI animals after disappearance of antibodies. It is worth mentioning that titer as low as $16-24$ could prevent the virus detection. The half life of maternal antibodies was found to be 5-11 days. The continuous production of BVDV due to persistent infection may account for this phenomenon.

The decline of passively derived BVDV antibody in immunocompetent calves is considerably slower. In calf No. 12 in the last sample at 18 weeks of age, a BVDV antibody titer of 32 was found. Brar et al. (1978) reported that passively acquired BVDV antibodies had a half life of approx. 21 days. Our finding in calf No. 12 coincided with this, as the BVDV titer decreased 5 dilution steps in 16 weeks, corresponding to a half life of approx. 3 weeks.

The 11 PI calves examined showed no clinical signs suggestive of persistent infection. Several data have been published that a significant proportion of PI animals are clinically normal and reach the breeding or slaughter age (Coria \& McClurkin 1978, Cutlip et al. 1980, Straver et al. 1983, Meyling 1984). These observations emphasize the importance of laboratory testing in recognition of apparently healthy PI animals.

Our results show that the half life of passively transferred antibody is reduced by several days in PI calves and, depending on the initial antibody titer, PI calves can be recognized by laboratory test at different times during the first 8 weeks of life. The results furthermore indicate that PI animals may be identified by virus isolation as early as 2 months after birth. 
V.Palfi

National Veterinary Laboratory, Copenhagen, Denmark.

H.Houe

Department of Clinical Studies, Division of Internal Medicine, Royal Veterinary and Agricultural University, Frederiksberg, Denmark.

J.Philipsen

Kjellerup and Skægkær Animal Hospital, Silkeborg, Denmark.

\section{References}

Brar JS, Johnson DW, Muscoplat CC, Shope RE, Meiske JC: Immunity to infectious bovine rhinotracheitis and bovine viral diarrhoea viruses: Duration and effect of vaccination in young calves. Amer. J. vet. Res. 1978, 39, 241-244.

Coria MF, McClurkin AW: Specific immune tolerance in an apparently healthy bull persistently infected with BVD virus. J.Amer. vet. med. Ass. 1978, 172, 449-451.

Cutlip RC, McClurkin AW, Coria M F: Lesions in clinically healthy cattle persistently infected with the virus of bovine viral diarrhoea-glomerulonephritis and encephalitis. Am. J. Vet. Res. 1980, 41, 1938-1941.
Duffell SJ, Harkness JW: Bovine virus diarrhoeamucosal disease infection in cattle. Vet. Rec. 1985, 117, 240-245.

Meyling A: Detection of BVD virus in viremic cattle by an indirect immunoperoxidaze technique. In: (McNulty MS, McFerran JB eds.). Recent Advances in Virus Diagnosis Martinus Nijhoff Publishers, Boston, 1984, 37-46.

Meyling A, Jensen AM: Transmission of bovine diarrhoea virus (BVDV) by artificial insemination (AI) with semen from persistently infected bull. Vet. Microbiol. 1988, 17, 97-105.

Qvist $P$ : An enzyme-linked immunosorbent assay for the detection of serum antibodies to bovine virus diarrhoea virus. Acta Vet. Scand.

Submitted.

Straver PJ, Journee LH, Binkhorst GJ: Neurologic disorders,virus persistence and hypomyelination in calves due to intrauterine infections with bovine virus diarrhoea virus. II. Virology and Epizootiology. Vet. Q. 1983, 5, 156-164.

(Received August 17, 1992; accepted December 18, 1992).

Reprints may be requested from: Hans Houe, Department of Clinical Studies, Division of Internal Medicine, Royal Veterinary and Agricultural University, Bülowsvej 13, DK-1870 Frederiksberg, Denmark. 
